\title{
AN OPEN LETTER TO \\ PROFESSOR EMERITUS \\ SETON HOWARD FREDERICK LLOYD
}

C.B.E., M.A., F.B.A., F.S.A., A.R.I.B.A.

\section{Dear Seton,}

It gives us the greatest pleasure to be able to celebrate your eightieth birthday on 3 oth May 1982 by the dedication of this year's Iraq to you, ten years after the British Institute of Archaeology at Ankara honoured you with a more formal Festschrift.

It is particularly appropriate that we should do so in a number of ways. First, you are senior in Mesopotamian archaeology to our own School, whose jubilee year we celebrate, since at the time of its foundation on I th January 1932, you had already been excavating for two years with Henri Frankfort on the Diyala, an excavation which was to become a classic of method and publication.

The work which you next undertook was very welcome both to Mesopotamian archaeology and to our own Journal and School: your Sinjar survey of $1937-3^{8}$, which placed the archaeology of this important and fascinating area firmly on the map, and led directly in later years to the School's dramatically successful excavations at Tell al Rimah and Tell Taya.

As Adviser to the Government of Iraq's Directorate General of Antiquities in the years I939-1949, you conducted the Sinjar soundings at Grai Resh and Tell Khoshi, reported in Iraq 1940, the first appearance in our Journal of the beautiful architectural plans and drawings which are so much your personal hall-mark.

Throughout the excitements of the war years in Iraq, you managed to carry out a substantial programme, at Tell 'Uqair (I940-4I) and Tell Hassuna (1943-44), as well as a happy collaboration with Taha Baqir at 'Aqar Quf (1942-44) to which we owe the war-time supplements of Iraq (I944 and I945). After the war came your collaboration with Fuad Safar at Eridu, further fundamental work, distinguished studies on which you presented in this Journal, to Sir Leonard Woolley (rg6o) and Sir Max Mallowan (I 974). It is gratifying to hear that the final publication of these important excavations, long delayed through no fault of your own, is now in the press in Baghdad.

You left Iraq for the Directorship of the British Institute of Archaeology at Ankara in I 949, but during your twenty years in Iraq, you had made such a distinctive mark on Mesopotamian archaeology that your successors have constantly found themselves following in your foot-prints. Nor had you abandoned Mesopotamia, as reference to the bibliography of your writings, to be included in the Autumn number of this Journal, will establish. Perhaps the crown of this work, if we may select, is that group of three admirable books in which you have laid before us your profound knowledge of Iraq : Foundations in the Dust (1947, delightfully illustrated by your wife Hydie, and recently deservedly re-issued) ; Mounds of the Near East (1963); and The Archaeology 


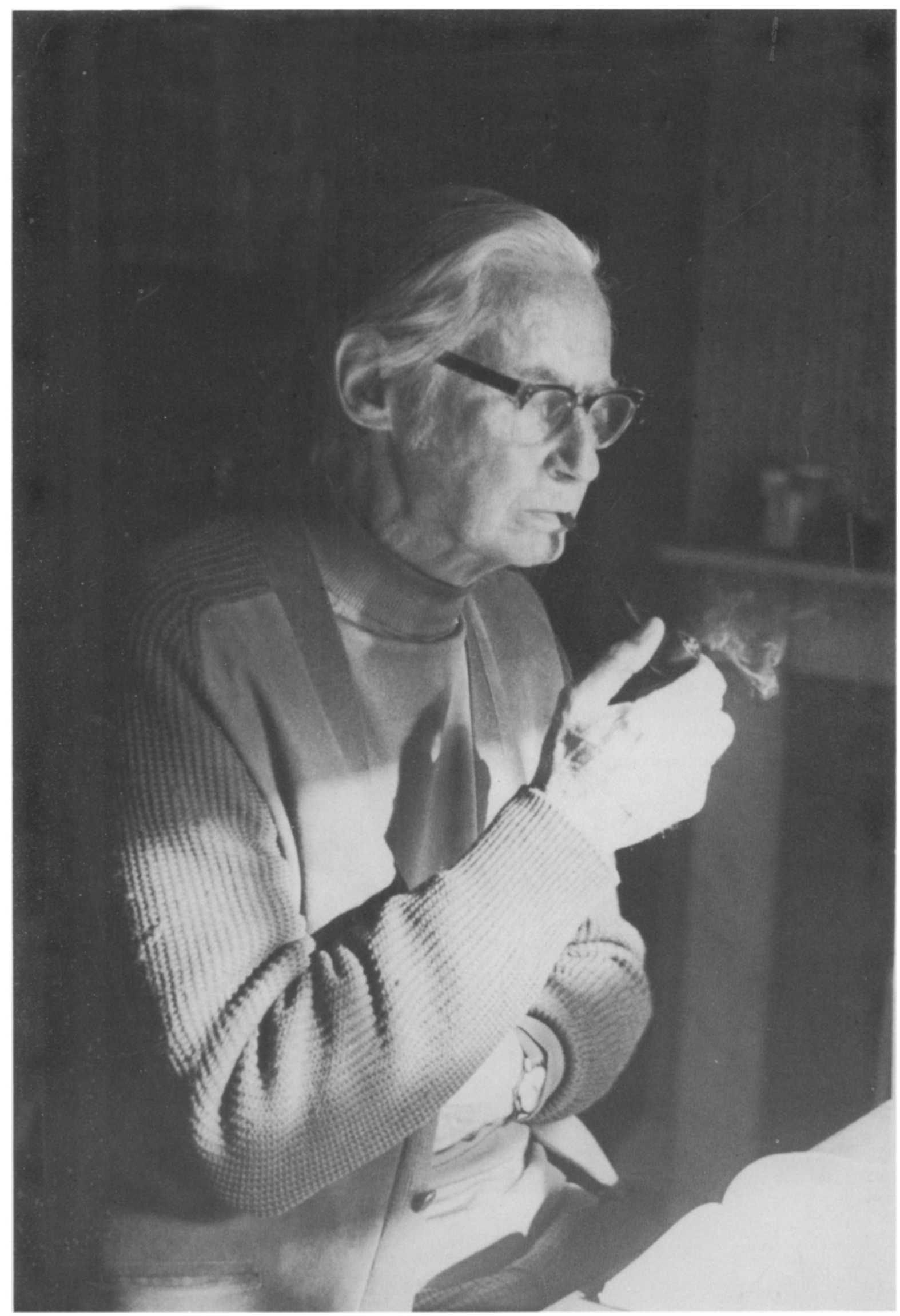


of Mesopotamia (1978). Even alone these would represent an outstanding achievement.

In a sense, your move to the Professorship of Western Asiatic Archaeology at the Institute of Archaeology, University of London, in 1962, was a return to Mesopotamia from the Anatolian highlands. You were then to confer the benefits of your knowledge and experience of Iraq on the large number of students who had the privilege of studying under you, including the undersigned. It was a time which we all remember with gratitude and affection.

Since your retirement in 1969 , you have continued to participate fully in the activities of the School. In 1975 you gave to us the first Bonham Carter Memorial Lecture, a vivid and unforgettable survey of Mesopotamian architecture, in which you recreated for us the appearance and feel of the ancient Mesopotamian city. On the death of Sir Max Mallowan, you took over the office of our President, which you have filled with great distinction. As a token of our permanent debt to you, and in recognition of your services to Mesopotamian archaeology, our Council presented to you in 1979 the Gertrude Bell Memorial Medal : we print below the photograph of the presentation to you by our Chairman, Professor D. J. Wiseman.

For all these reasons then it is fitting to dedicate to you, with an informality which I am sure that you will forgive, this volume of Iraq, which contains contributions from your colleagues, former students and some of the younger generation of Mesopotamian archaeologists. Your abiding influence is well attested by the constant recurrence of your name in their bibliographies, which cover an extended range.

On your birthday therefore we salute your achievements and send you all our warmest greetings. It has been a high privilege for all of us to have known you as excavator, scholar, teacher and friend.

Yours affectionately,

J. D. H.

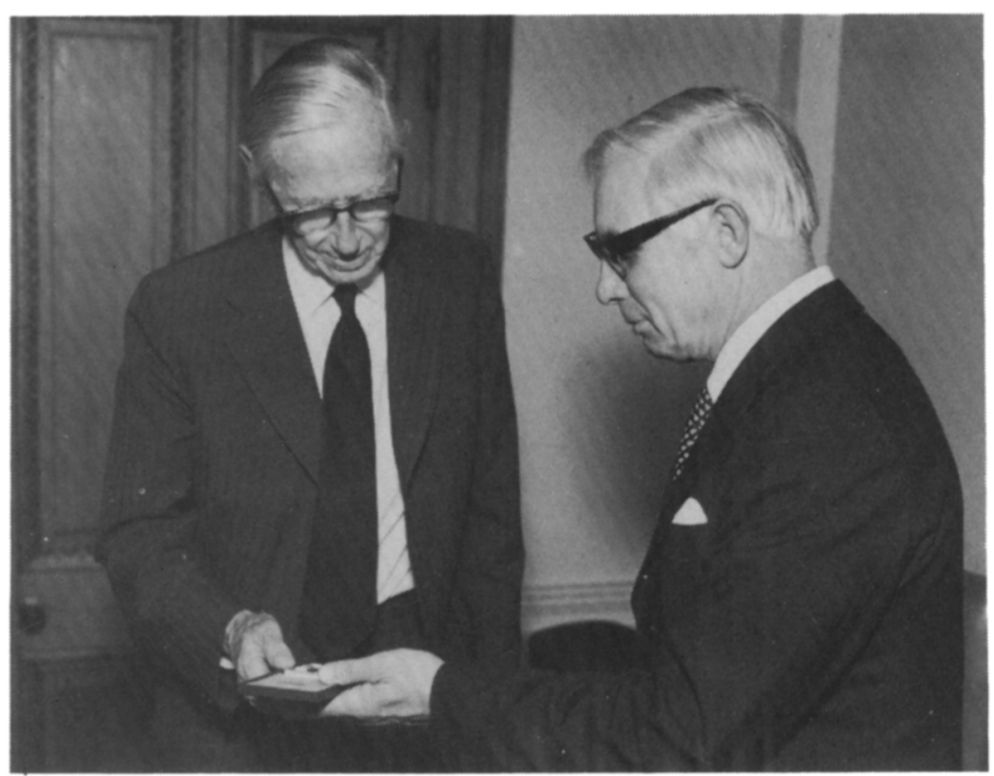

